\title{
Quality of Life and Spirituality in The Context of Chemical Dependency
}

\author{
Irami Araújo-Filho ${ }^{1 *}$, Jurema Ribeiro Luiz Goncalves ${ }^{2}$, Nathalia Silva Gomes ${ }^{3}$, Eliseu da Costa \\ Campos $^{4}$ and Amália Cinthia Meneses Rêgo ${ }^{5}$ \\ ${ }^{1}$ Department of Surgery, Federal University of Rio Grande do Norte, Brazil \\ ${ }^{2}$ Psychiatric Nursing, Ribeirão Preto College of Nursing, Brazil \\ ${ }^{3}$ Health Care, Brazil \\ ${ }^{4}$ Health Management, Brazil \\ ${ }^{5}$ Health Science, Potiguar University, Brazil
}

*Corresponding author: Irami Araújo-Filho, Department of Surgery, Federal University of Rio Grande do Norte, Brazil.

To Cite This Article: Irami Araújo-Filho. Quality of Life and Spirituality in The Context of Chemical Dependency. Am J Biomed Sci \& Res. 2019 3(6). AJBSR.MS.ID.000728. DOI: 10.34297/AJBSR.2019.03.000728

Received: May 16, 2019 | Published: July 10, 2019

\begin{abstract}
Objective: To describe the sociodemographic characteristics, quality of life and spirituality of users of alcohol and other drugs at the Center for Psychosocial Care in the Triângulo Mineiro region of Minas Gerais, Brazil, comparing levels of quality of life and spirituality according to sex.

Methods: A cross-sectional study was carried out with chemical dependents from this region of Brazil. The questionnaire on Sociodemographic and Economic Profile, quality of life (WHOQOL-bref), and spirituality, religiosity and personal beliefs (WHOQOL - SRPB) was applied.

Results: A total of 232 chemical dependents were included in the study and $80.4 \%$ were male. In the Physical, Psychological, Social and Environmental domains, men presented higher scores than women. The women obtained a worse score in the Psychological and Environmental areas.

Conclusion: The importance of proposing a Single Therapeutic Plan more adapted to the female reality, considering spirituality as an essential strategy for the recovery and handling of quality of life.
\end{abstract}

Keywords: Spirituality; Quality of life; Psychotropic drugs; Drug addicts; Psychosocial rehabilitation; Treatment centers

\section{Introduction}

Drug misuse is a global issue causing concerns in parents, educators, health professionals and society in general. Humanity's consumption of drugs is an old phenomenon and has accompanied us since the earliest civilizations, but its challenges are current1. It is estimated that 246 million people have used psychoactive substances within a year. Drug consumption in the world becomes more relevant considering that more than one user in ten present disorders and dependence [1-3], in which chemical dependence is characterized by the presence of symptoms where the individual prioritizes the use of the drug, in detrimental to necessities of life and responsibilities, causing problems in the biopsychosocial scope proportional to consumption [2]. In this perspective, it is evident the permanence of the prejudice and stereotype about the chemical dependent, affecting several aspects of life. Women and men develop different consumer profiles and confrontations. According to the Annual Report on the Evolution of the Drug Phenomenon in the European Union, published by the European Monitoring Center for Drugs and Drug Addiction (EMCDDA) based in Lisbon, women who use drugs carry more significant stigma than men. The report highlights the importance of finding answers that are more tailored to women, and which address their problems and the specific female needs [4].

About 10 percent of the world's major urban centers consume abusive psychoactive substances, regardless of age, sex or level of education, reaching all social classes. In Brazil hospitalizations for alcohol dependence, on average, account for $90 \%$ of all admissions due to drug use, with a predominance of men, in a ratio 10 times higher than women [5]. Due to the relevance of this public health problem, the Brazilian government developed a 
policy of comprehensive care for alcohol and other drug users to provide individuals who consume psychoactive substances outside the hospital environment, offer support from the Centers for Psychosocial Alcohol Care and other Drugs (CAPSad) [6]. Psychiatric care programs have for decades been based on the separation of the patient from the community, centralizing the decision-making power of the psychiatrist. In this model, individualized care did not exist, and treatment was governed by medication and containment actions, seeking remission of symptoms. With the proposed new vision on health and the mentally ill, it was possible to elaborate therapeutic plans through a multidisciplinary approach, with the collaboration of a health team that allows a more complete and humanized care [6-8].

Nursing assumes a fundamental role in this team, performing actions such as reception, therapeutic communication, nursing consultation, medication administration, unit management, among other activities, which places the nurse figure as the main element within CAPSad [7]. The CAPSad, are open to the care of both sexes, and in general, the demand is higher on the part of the men. The analysis of patterns of alcohol consumption and other drugs in the Brazilian urban population showed a significant difference at some point in life in males compared to females. In this context, studies on the prevalence and incidence of alcohol and other drugs, although there are cultural variations characteristic of each country, usually report that male sex stands out as the largest consumer, and also in the most significant number of alcohol users and other drugs in care in CAPSad [6-8]. Thus, CAPSad is evaluated as a promising service due to the promotion of conceptual changes, values and vision of care, in which the use of therapeutic and assertive communication without confrontation is capable of promoting the development and improvement of Quality of Life (QL) [9].

Therefore, it is essential to promote better adherence to the proposed treatment, allowing the user to have his/her needs heard and respected particulars, providing an integral and humanized therapy in accordance with the guidelines of the Unified Health System (SUS), favoring the improvement of the considering the well-being and Quality of Life (QL) of the Brazilian public service user, in an equitable and egalitarian manner [7,10,11]. Nahas et al. [11,12] argue that QL is a particular concept to the individual or society, such combination being associated with variables such as health status, job satisfaction, economic issues, leisure and recreation, family relationships, spiritual well-being and the practice of pleasurable practices $[11,12]$. Recognizing spirituality as an essential ally for reaching the expanded concept of health and QL, the World Health Organization stresses that health is a dynamic state of complete physical, mental, spiritual and social well-being and not just the absence of disease, thus including religiosity, spirituality and personal beliefs in the concept of QL.

In the same direction, the Brazilian Federal Constitution, in Article 196, states that health is the right of everyone and the duty of the State, guaranteed through social and economic policies universal and equal access to actions and services for promotion, protection and recovery. Besides, it broadens the concept of health as the result of sufficient conditions of food, housing, education, income, environment, labor, transportation, employment, leisure, freedom, freedom of religion, access to and possession of land and access to services of health $[13,14]$. For years, spirituality and religiosity were considered as synonyms, until at the beginning of the nineteenth century these concepts began to present distinctions. Spirituality consists in a search for meaning and understanding of the meaning of life, a search for something greater than itself, through concepts that transcend the tangible, and may or may not include formal religious participation [9-12]. On the other hand, Religiosity refers to religious life and its actions. It is the relationship that the individual possesses with this belief $[15,16]$. Even today, this is a problematic issue for health professionals, which raises an extensive debate in search of consensus $[16,17]$.

The balance between spirituality, physical and mental health, has shown beneficial results in heart disease, blood pressure, immunity, resistance to infectious diseases, pain and mortality processes, directly influencing the QL of the population. In this context, people demonstrate a greater sense of purpose and meaning in life, greater resilience when exposed to stress, and lower incidence of alcohol and other drug use $[10,18,19]$. In the search for the more effective and integral treatment of the abuse of licit or non-licit chemical substances, it is essential to listen to the user in their fears and doubts, to draw up action plans that favor QL. Thus, practical experience with these patients points to the use of spirituality and religiosity in recovery centers, for example, as an essential strategy for coping with dependence on alcohol and other drugs [20,21]. CAPSad is evaluated as a service that promotes conceptual changes, values and the vision of care, whose emphasis is on singularity and diversity to go beyond stigma and pre-established concepts, providing social reintegration and improvement of QL. Thus, activities are centered on the promotion of $\mathrm{QL}$, ranging from those related to the maintenance of daily life and self-care to those associated with the recreation of social life. In this sense, the individual is seen in his everyday life and is inserted socially [6]. Given the above, this study aimed to describe the sociodemographic characteristics, quality of life and spirituality of users of alcohol and other CAPSad drugs in the Triangulo Mineiro region, comparing levels of quality of life and spirituality according to sex.

\section{Methods \\ Ethical aspects}

The research project was submitted to the Research Ethics Committee of the Federal University of Triângulo Mineiro (UFTM) and approved under protocol number 2204. Each volunteer signed a Free and Informed Consent Term (TCLE) according to Resolution 466/12 /CEP/CONEP. The objective of the study was clarified, as well as the guarantee of the anonymity and total freedom of the volunteer to give up the research at any time. Authorities were requested to the respective city halls and the CAPSad of each municipality. After the necessary authorizations, data collection was started.

\section{Study Design}

A quantitative cross-sectional study carried out in the CAPSad, linked to the municipal health services of the Triângulo Mineiro 
Region: Uberaba, Uberlândia and Araxá, Minas Gerais State/Brazil. These units cover $100 \%$ of the health units in that region. Data were collected from March to June 2018.

\section{Sample population}

Inclusion and exclusion criteria: The study population consisted of users of alcohol and other drugs being treated at CAPSad. The sample was selected for convenience, within the period of data collection, considering the inclusion criteria: age equal to or greater than 18 years, of both sexes, being in treatment, agreeing spontaneously to participate in the study after being invited and signing the Term of Free and Informed Consent. The following were excluded from the study: users who demonstrated any condition that could make it difficult to understand items in the research questionnaire and were under intoxication due to drug use.

\section{Study Protocol}

The data were collected by the researcher, through interviews with an average duration of 30 minutes, in a private place and individually during the waiting period between the activities developed in CAPSad. Three instruments were applied: a form developed by the authors to identify the Socio-demographic and Economic Profile of the users, containing the variables: sex, age, income, marital status, vocational training course, receipt of government benefits and housing. Subsequently, the QOL evaluation instruments, called WHOQOL-bref and WHOQOL SRPB, were applied. The WHOQOL-bref is an instrument developed by WHO, later validated in the Brazilian version by Fleck et al. containing 26 questions, of which two are general perceptions about QoL and health and 24 inquiries related to the physical, psychological, social and environmental domains [22]. The WHOQOL - SRPB, an instrument developed as part of the WHOQOL GROUP work, later validated by Panzini, Porto Alegre, State of Rio Grande do Sul, 20062009. Composed of 32 items and eight facets to assess how spiritual, religious, and personal beliefs are related to QOL. The WHOQOLbref and SRPB were analyzed separately with their respective syntaxes. The score varied from 0 to 100 , with the highest number corresponding to the best QV [19].

\section{Analysis of results and statistics}

The data were typed in an EXCEL $\AA$ spreadsheet, in double entry, to evaluate the consistency of the data. Then exported to the Statistical Package for Social Science (SPSS) application, version 17.0, to perform the statistical analysis. For the comparison of numerical variables, the Student t-test and the Mann-Whitney test were used according to the normality of the data. The results were considered statistically significant when $p \leq 0.05$. The KolmogorovSmirnov test verified the normality of the data.

\section{Results}

Were invited 411 users, of which 232 accepted to participate in the study, and $43.5 \%$ did not show interest, refusing their participation. Of the 232 people interested in participating in the study, 187 were male and 45 female, with a predominance of the age group between 36 and 59 years. As for income, 39.2\% received up to a minimum wage. See Tables 1-5 on the profile of the patients evaluated and the results referring to the study objective based on the sample population.

\begin{tabular}{|c|c|c|}
\hline Variable & $* n-232$ & $\%$ \\
\hline \multicolumn{3}{|c|}{ Sex } \\
\hline Male & 187 & 80,6 \\
\hline Female & 45 & 19,4 \\
\hline \multicolumn{3}{|c|}{ Age } \\
\hline $18-35$ years & 73 & 32,7 \\
\hline $36-59$ years & 137 & 61,4 \\
\hline$\geq 60$ & 13 & 5,8 \\
\hline Did not answer & 9 & \\
\hline \multicolumn{3}{|c|}{ Monthly income } \\
\hline Up to 1 salary & 91 & 39,2 \\
\hline $1-3$ salaries & 89 & 38,4 \\
\hline 3 wages or more & 11 & 4,7 \\
\hline No income & 34 & 14,7 \\
\hline Did not answer & 7 & \\
\hline \multicolumn{3}{|c|}{ Marital status } \\
\hline Not married & 127 & 55,0 \\
\hline Married & 26 & 11,3 \\
\hline Stable union & 35 & 15,2 \\
\hline Separated, Divorced, Widowed & 35 & 15,2 \\
\hline Widower & 8 & 3,5 \\
\hline Did not answer & 1 & \\
\hline \multicolumn{3}{|c|}{ Vocational course } \\
\hline Not & 146 & 62,9 \\
\hline Yes & 86 & 37,1 \\
\hline \multicolumn{3}{|c|}{ Government benefit } \\
\hline Not & 163 & 70,3 \\
\hline Yes & 69 & 29,7 \\
\hline \multicolumn{3}{|c|}{ Housing } \\
\hline Own & 129 & 55,6 \\
\hline Leased & 37 & 15,9 \\
\hline Assigned & 23 & 9,9 \\
\hline Others & 43 & 18,5 \\
\hline
\end{tabular}

Note: Sample population.

Table 2: Distribution of patients according to first use drug.

\begin{tabular}{|c|c|c|}
\hline Drug & *n (232) $^{(23}$ & \% \\
\hline Alcohol & 116 & 50 \\
\hline Marijuana & 78 & 33.6 \\
\hline Cocaine & 19 & 8.2 \\
\hline Crack & 13 & 5.6 \\
\hline Others & 6 & 2.6 \\
\hline
\end{tabular}

Note: Sample Population. 
Table 3: Characterization of the domains of the WHOQOL- bref (QL) of patients.

\begin{tabular}{|c|c|c|c|c|}
\hline Domain & Average & *sd & Min. & Max. \\
\hline Physical & 60.6 & \pm 18.46 & 14.29 & 100 \\
\hline Psychological & 56.96 & \pm 18.56 & 0 & 91.67 \\
\hline Social & 54.48 & \pm 21.77 & 0 & 100 \\
\hline Environmental & 53.59 & \pm 16.45 & 16.45 & 93.75 \\
\hline
\end{tabular}

Note: Standard deviation (SD).

Table 4: Characterization of the WHOQOL-SRPB Domains (spirituality) of the patients.

\begin{tabular}{|c|c|c|c|c|}
\hline Domain & Average & Median & Minimum-Maximum & *sd \\
\hline Spiritual connection & 3.5 & 3.87 & $1.00-5.00$ & 1.06 \\
\hline Meaning of life & 3.64 & 3.75 & $1.00-5.00$ & \pm 0.83 \\
\hline Admiration & 3.46 & 3.75 & $1.00-5.00$ & \pm 0.99 \\
\hline All & 3.21 & 3.25 & $1.00-5.00$ & \pm 0.88 \\
\hline Spiritual strength & 3.54 & 3.75 & $1.00-5.00$ & \pm 1.00 \\
\hline Inner peace & 2.27 & 3.5 & $1.00-5.00$ & \pm 0.93 \\
\hline Hope and optimism & 3.75 & 4 & $1.00-5.00$ & \pm 0.78 \\
\hline Faith & 3.7 & 4 & $4.00-5.00$ & \pm 1.7 \\
\hline General & 14.04 & 14.62 & & $\pm 2.92-19.50$ \\
\hline
\end{tabular}

Note: Standard deviation (SD).

Table 5: Comparison of QL levels and spirituality between genders.

\begin{tabular}{|c|c|c|c|c|c|}
\hline \multirow{3}{*}{ Domains } & \multicolumn{5}{|c|}{ Gender } \\
\hline & \multicolumn{2}{|c|}{ Male } & \multicolumn{2}{|c|}{ Female } & \multirow{2}{*}{ p value } \\
\hline & Central trend & Dispersal & Central trend & Dispersal & \\
\hline \multicolumn{6}{|c|}{ WHOQOL-Brief } \\
\hline Physical $^{1}$ & 61.69 & 18.34 & 56.11 & 18.53 & 0.07 \\
\hline Psychological $^{2}$ & 58.33 & $45.83-70.83$ & 50 & $33.33-70.83$ & 0.01 \\
\hline Social $^{2}$ & 58.33 & $41.67-75.00$ & 41.67 & $33.33-66.67$ & 0.07 \\
\hline Environmental $^{2}$ & 56.25 & $48.88-65.63$ & 43.76 & $35.94-60.94$ & 0.05 \\
\hline \multicolumn{6}{|c|}{ WHOQOL-SRPB $^{3}$} \\
\hline Spiritual Connection & 3.75 & $2.75-4.00$ & 4 & $3.50-4.50$ & 0.03 \\
\hline Sense in life & 3.75 & $3.25-4.00$ & 3.75 & $2.88-4.25$ & 0.42 \\
\hline Admiration & 3.75 & $3.00-4.00$ & 3.5 & $2.63-4.00$ & 0.44 \\
\hline Totality and integration & 3.25 & $3.00-4.00$ & 3 & $2.50-3.50$ & 0.01 \\
\hline Spiritual strength & 3.75 & $3.25-4.00$ & 3.75 & $3.00-4.25$ & 0.94 \\
\hline Inner peace & 3.5 & $2.75-4.00$ & 3.25 & $2.00-3.75$ & 0.05 \\
\hline Hope and optimism & 4 & $3.50-4.25$ & 4 & $3.13-4.25$ & 0.96 \\
\hline Faith & 4 & $3.50-4.25$ & 4 & $3.38-4.75$ & 0.72 \\
\hline Student t-test for independent & central tendency & $\begin{array}{l}\text { scatter }=\text { star } \\
\text { persion }=\text { P2 }\end{array}$ & ; 2; 3. Mann-W & (central ten & nedian; \\
\hline
\end{tabular}

\section{Discussion}

The findings in the present study, concerning the average age of the users, showed in their majority age between 36-59 years, similar to another survey of the subject [23]. Regarding marital status, singles and separated accounted for a percentage of $70.2 \%$, that is, the vast majority of those interviewed reported not having a partner, nor maintaining some stable relationship. Studies have shown that marital status is an important aspect to be considered as a risk factor for abusive drug use [9,23]. A study of caregivers of chemical dependents assessed care overload and found that in most situations caregivers were wives and had depressive symptoms, pointing to lack of sexual interest as a relevant and limiting factor in family support [24]. Low schooling, coupled with the fact that $77.6 \%$ has a family income of less than three 
minimum wages per month, negatively interferes with the prospect of social reintegration. The lack of motivation and the discontinuity of the study and work processes interrupt in an early form the activities related to teaching. Interventions are needed to improve professional qualification and entry into the labor market, as lack of employment and unemployment further fuel low self-esteem, perpetuating regular self-defeating habits.

The users inserted in the CAPSad, are in the most productive age group, being more than $61 \%$ are between $36-59$ years of age. These data help us understand the impact that drugs have on contemporary society. Studies point to marijuana as the most commonly used illicit drug due to easy access and low cost, popularly considered as less aggressive drug and reduced social stigmas [25]. Studies show that among individuals who experience the substance, on average $10 \%$ will become daily users and 20 $30 \%$ will consume weekly $[25,26]$. Research conducted in several countries has shown that young people are increasingly in contact with drugs and start to drink alcoholic beverages at an earlier age $[26,27]$. This makes the scenario even more severe since the early initiation of alcohol use is associated with a higher probability of problems related to their consumption and dependence in adult life. In a survey conducted in Brazil on the use of psychotropic drugs (including alcohol) among elementary and middle school students (the majority between 10-18 years of age) has pointed out the severity of use at early ages. A national survey with 17 capitals showed that $65.2 \%$ had already had alcohol once in their lifetime and $11.7 \%$ had frequent drinking $[26,27]$. Another national-wide trial presented an alarming rate of $19.2 \%$ alcohol dependence among 18-24-year-olds. The abuse of alcohol and other drugs is of concern because of the consequences that the individual may suffer through adult life. The onset of alcohol consumption by adolescents (14-17 years) starts on average at 13.9 years and by young adults (18-25 years) at 15.3 years [28].

In both social and abusive use, alcohol is the drug most consumed in the world when comparing licit and illicit drugs. According to WHO data, more than 2 billion people consume alcoholic beverages. Misuse is one of the main factors contributing to the decline in global health, accounting for thousands of direct or indirect deaths. Concerning Latin America, alcohol assumes the importance of a more significant impact. About $16 \%$ of the useful lives lost on this continent are related to the misuse of this substance, which is four times higher than the world average [29]. Worldwide, although consumption among men is higher, there is a trend of convergence between men and women in the pattern of use among young people, especially about high doses in a short period, the so-called "heavy drinking" [28]. In the present study, alcohol appears as the first drug in $50 \%$ of users. This high-risk consumption is associated with several consequences, is one of the leading causes of morbidity and mortality among students, as they end up involved in traffic accidents, acts of violence, sexual abuse, sexual harassment, health problems, decreased academic productivity and interpersonal problems [28].

The initial use of drugs happens when the person seeks acceptance by a social group, a challenge to the norms, curiosity, will to feel the effects of the substance, among others. Regardless of motive, the onset occurs in adolescence. This finding intensifies the demand for preventive programs for this age group to reduce the harms of early use, providing better QL conditions [30]. Drug use and QL have been discussed in studies that show lower QL scores among users compared to the general population or other patients with chronic diseases [30,31]. In Brazil, the results are no different. The association between the lower QL scores and the use of alcohol and other drugs reinforces the negative influence of drug use on the perception of QL $[31,32]$. Spirituality can be presented as an expression of feelings in a solitary or collective way, linked to the experiences of the individual, not necessarily related to a more structured religion or belief [17]. Spirituality manifested in religiosity can influence the mental health of individuals by regulating their behaviors, such as healthy behaviors and lifestyle, making the person think about how they eat or abstain from food, drink or not, having sex, using legal or illegal substances, following prescriptions or medical treatments, raising children and marital relationship [17].

Social support is available, used as psychosocial support, since people feel that they belong to a group, which facilitates adherence to health promotion programs. It can be seen that religious confrontation can be positive or negative. It is positive when it is channeled to find spiritual lessons in stressful moments or to count on the help of companions of the same faith, seeking in the religion a direction, support, and comfort. The negative coping is in passive attitudes, waiting for extraordinary forces to control and resolve the situation. The individual can understand stress as a divine punishment or a demonic act and therefore raises questions about merit and justice [33,34]. Research points to religiousness as a protective factor for drug use among people who attend church regularly, who practice religious precepts or have received religious education in childhood.

Regarding spirituality, in the Spiritual Connection domain, women achieved a statistically significant higher score. In the totality and integration domain, it was the men's turn to present the best results. Religiousness appears as an aid to the individual, raises optimism, offers emotional support, promotes resilience, reduces stress, anxiety and helps in socialization [16,35].

The religious/spiritual approach should be guided by the neutrality of the health professional, respecting the patient's choices. But it is necessary to understand and work alongside his belief so that it does not become a hindrance in the personal development of health promotion [6]. The religious experience enables another look and a better understanding of the world, since the patient remains the same person, but changes the way of understanding the situation [16]. Drug use is widespread in contemporary society. But despite this, the abuse of these substances carries with it a high weight of prejudice and stigma. Society usually labels the involvement or abuse negatively in consumption. Although the presence of social discrimination is evident concerning any dependence on the substance, women seem to be even more stigmatized than men. Relevant stereotypes are attributed to it, such as the tendency towards promiscuity in 
the search to maintain the addiction, failure or failure to fulfill the family role and others. The family role, not only as a parent but also as a maintainer of the home, often in the popular conception, is feminine rather than a male position $[36,37]$.

Society seems to be less tolerant and more demanding about the role of women. Despite all the changes of values, and "revolutions" in social relations between men and women, these stereotypes make it difficult for women to access treatment, either through shame or a sense of failure, that is, the structure of specialized health services that are concatenated to the male profile. Given this scenario, research is needed to reflect on this issue, to unveil the smallest female presence in the CAPSad and support policies that better serve women in their needs, such as care of their youngest children, private bathrooms and environments more adapted to the female reality [38]. The process of recovery of health is continuous; therefore, the nursing team must be prepared to help the chemical dependent on maintaining their new lifestyle after treatment and throughout the process of adaptation and social reintegration. Behavioral changes are needed, that is, a new way of life.

This process should be dynamic, and to maintain the effectiveness of the Singular Therapeutic Plan (STP), it is essential that patients be periodically reassessed, listening to the user and their family members, together with professionals from the multiprofessional team. Only in this way is it possible to offer a service that promotes integrated practices and transformative actions [39]. In this perspective of care, it is necessary to restructure nursing care to the users of mental health services. The logic of care must be interdisciplinary and comprehensive offering different types of therapeutic activities. The restructuring goes beyond the nursing consultation or administration of medications and causes significant changes in the care and treatment of patients who use this health service. In changing paradigms in the health care process and care restructuring, the nurse assumes a strategic position as a member of the team. An integrated team favors an environment of welcoming, respecting and developing individual capacities [40].

There were limitations in the development of this study concerning data collection since the patients showed deficits of concentration and difficulty of understanding referring to the instrument of data collection /questionnaire. Due to the peculiar heterogeneity of the sample population, there were difficulties in the application and interpretation of the evaluation questionnaire on quality of life for a community with different characteristics. This made it difficult to generalize the results to the entire population since it was applied in a regional sample. Contributions to the area of nursing the findings of this study contribute to the recognition of alterations in $\mathrm{QL}$ experienced by the patients, which may compromise the therapeutic plan, making treatment adherence difficult. In this context, the present study contributes to the advancement in knowledge and debate about the needs of nursing care adapted to this type of population, with actions directed to the individual and collective needs of the users, valuing the importance of QL in coping with the disease, respecting the differences of gender, religiosity and spirituality, promoting a more humane and practical assistance.

\section{Conclusion}

Despite being a licit drug, alcohol in its many forms of consumption causes a social impact in several dimensions. Marijuana is the leading drug in the beginning when it comes to illicit drugs. Thus, the results of this research justify the adoption of public policies that intervene in this mechanics of the consumption of both alcohol and marijuana in early life, especially among young adults.

The role of the family becomes vital in any sphere of the individual's life. In this way, it is necessary for nursing to devote a differentiated look to the users' families to help them to strengthen and face the problems caused by addiction to alcohol and other drugs, to join forces in the search for treatment. When comparing QL between the sexes, the data point out the women with the worse score in the Psychological and Environmental domains. Because of this, they deserve special attention to provide QL improvement in women, proposing a PTS that is more adapted to the female reality, taking into account spirituality as an essential factor for the recovery and enhancement of QL.

Spirituality is an essential tool in the treatment of chemical dependents and can be used by nursing as an ancillary tool in the search for the personal development of the user, regardless of specific religious beliefs or links. Much has been advanced on the subject of chemical dependency, but there is still much to be tackled. Currently, many privately managed drug user recovery clinics use religion and spiritual attention in treating and improving $\mathrm{QL}$, achieving relative success. Therefore, it is necessary for nursing to develop new research that addresses the topic of QL and spirituality in addicted patients. Such research should pay attention to the social and biological differences that distinguish men and women, thus orienting the actions of nursing and multidisciplinary health team, promoting a SUS that is more humane and integral to all.

\section{References}

1. Degenhardt L, Glantz M, Evans-Lacko S, Sadikova E, Sampson N, et al. (2017) Estimating treatment coverage for people with substance use disorders: an analysis of data from the World Mental Health Surveys. World Psychiatry 16(3): 299-307.

2. (2017) European Monitoring Centre for Drugs and Drug Addiction (EMCDDA) 2017: Trends and Developments. European Monitoring of Drugs and Drugs Addiction p. 90.

3. (2016) United Nations Office on Drugs and Crime (UNODC). World Drug Report 2016. Report. United Nations p. 26-34.

4. (2017) Europäische Kommission Beobachtungsstelle für Drogen und Drogensucht. Health and social responses to drug problems a European guide. Publications Office of the European Union.

5. Ronzani TM, Mota DCB (2011) Políticas de saúde para atenção integral a usuários de drogas. A política do Ministério da Saúde para Atenção Integral aos Usuários Álcool e outras Drogas pp. 237-249.

6. Burke KP, Bianchessi DLC (2013) Work as a possibility of social (re) inclusion for users of a Psychosocial Attention Center (PAC) in their own perspective and the team's. Estudos e Pesquisa em Psicol 13: 957-976.

7. Kantorski LP, Mielke FB, Teixeira Junior S (2008) The work of the nurse in psychosocial care centers Trab. educ saúde Rio de Janeiro 6(1): 87106. 
8. Carvalho MDA, Silva HO, Rodrigues LV (2010) Perfil Epidemiológico dos Usuários da Rede de Saúde Mental do município de Iguatu, Ce. Rev Eletrônica Saúde Mental Álcool e Drogas 6(2): 337-349.

9. Zerbetto SR, Galera SAF, Ruiz BO, Zerbetto SR, Galera SAF (2017) Family resilience and chemical dependency: perception of mental health professionals. Rev Bras Enferm 70(6): 1184-1190.

10. Lacerda BM, Queiroga GM, Pinto V, Queiroga SM, Anunciada M et al. (2015) Perfil de usuários de drogas em centros terapêuticos do estado do Rio Grande do Norte 13(1): 54-65.

11. Nahas MV (2013) Atividade física, Saúde e Qualidade de Vida: Conceitos e Sugestões para um Estilo de Vida Ativo. Mediograf pp. 335.

12. Nahas DEMV, Rita DR a, Dos M, Puga S (2012) Resenha Do Livro "Atividade Física, Saúde e Qualidade de Vida: Rbce. pp. 513-518.

13. Dalmolin BB, Backes DS, Zamberlan C, Schaurich D, Colomé JS, et al (2011) Meanings of the health concept through the perspective of teachers in the health field. Esc Anna Nery.

14. Leticia CS (2015) Desafio: Concretização do direito à saúde pública no Brasil CONASS.

15. Reis LA, Menezes TMO (2017) Religiosity and spirituality as resilience strategies among long- Living older adults in their daily lives. Rev Bras Enferm 70(4): 761-766.

16. Fornazari AS, Ferreira RER (2010) Religiousness/spirituality in oncological patientes: life quality and health. Psic: Teor e Pesq 26(2): 265-272.

17. Pinto ÊB (2009) Espiritualidade e Religiosidade: Articulações. Revista de Estudos da Religião Dez p. 68-83.

18. Levin JS, Vanderpool HY (1987) Is frequent religious attendance really conducive to better health? Toward an epidemiology of religion. Soc Sci Med 24(7): 589-600.

19. Panzini RG, Maganha C, da Rocha NS, Bandeira DR, Fleck MP (2011) Brazilian validation of the Quality of Life Instrument related to spirituality, religion and personal beliefs. Rev Saude Publica 45(1): 153165.

20. Ferreira MCG, Tura LFR, da Silva RC, Ferreira M de A (2017) Social representations of older adults regarding quality of life. Rev Bras Enferm $70(4): 806-813$.

21. Panzini RG, Bandeira DR (2007) Coping (enfrentamento) religioso/ espiritual. Rev Psiquiatr Clín 34(1): 126-135.

22. Fleck MPA, Louzada S, Xavier M, Chachamovich E, Vieira G, et al. (2000) Aplicação da versão em português do instrumento abreviado de avaliação da qualidade de vida WHOQOL-bref. Rev Saude Publica 34(2): 178-183.

23. Silva CC, Costa MCO, Carvalho RC de, Amaral MTR, Cruz NL de A, et al. (2014) Initiation and consumption of psychoactive substances among adolescents and young adults in an Anti-Drug Psychosocial Care Center. Cien Saude Colet 19(3): 737-745.

24. Marcon RS, Rubira EA, Espinosa MM, Barbosa DA (2014) Quality of life and depressive symptoms among caregivers and drug dependent people. Rev Latino Am Enferm 20(1): 167-174.
25. Ribeiro M, Marques ACPR, Laranjeira R, Alves HNP, Araújo M, et al. (2005) Abuso e dependência da maconha. Rev Assoc Med Bras 51(5): 247-249.

26. Monteiro CFDS, Fé LCM, Moreira MAC, Albuquerque IEDM, Silva MG Da, et al. (2011) Perfil sociodemográfico e adesão ao tratamento de dependentes de álcool em CAPS-ad do Piauí. Esc Anna Nery 15(1): 9095.

27. Carlini EA, Carlos J, Galduróz F, Noto AR, Nappo SA. I National domiciliary survey about the use of psychotropic drug in Brazil: involving the 107 cities major of country - 2001.

28. Laranjeira R, Pinsky I, Zaleski M, Caetano R (2007) I Levantamento nacional sobre os padrões de consumo de Álcool. Secretaria Nacional de Políticas sobre drogas. pp. 76.

29. (2014) OMS - Organização Mundial da Saúde (unidoc). Relatório Sobre Drogas no Mundo.

30. Gabatz RIB, Schmidt AL, Terra MG, Padoin SMM, Silva AA, et al. (2013). Percepção dos usuários de crack em relação ao uso e tratamento. Rev Gaúcha Enferm 34(1):140-146

31. Jansen K, Mondin TC, Ores LDC, Souza LDDM, Konradt CE, et al. (2011) Mental common disorders and quality of life in young adulthoods: a population-based sample in Pelotas, Rio Grande do Sul State, Brazil. Cad saude publica 27(3): 440-448.

32. Levinson D, Rosca P, Vilner D, Brimberg I, Stall Y, et al. (2017) Binge drinking among young adults in an urban tertiary care emergency department in Israel. Isr J Health Policy Res 6(1):34.

33. Rebouças CBA, Araújo MM, Braga FC, Fernandes GT, Costa SC (2016) Evaluation of quality of life of visually impaired. Rev Bras Enferm 69(1): 64-70.

34. Souza VM, Frizzo HCF, Paiva MHP, Bousso RS, Santos AS (2015) Spirituality, religion and personal beliefs of adolescents with cancer. Rev Bras Enferm 68(5): 509-514.

35. Lenardt MH, Carneiro NHK, Binotto MA, Willig MH, Lourenço TM, et al. (2016) Frailty and quality of life in elderly primary health care users. Rev Bras Enferm 69(3): 478-483.

36. Sanchez Z van der M, Nappo SA (2007) Religiosity, spirituality and psychotropic drug use. Rev Psiquiatr Clínica 34(1): 73-81.

37. Marcon SR, Xavier JS, Barcelon AA, Espinosa MM, Barbosa DA (2014) Correlation between depressive symptoms and quality of life in users of psychoactive substances. Rev da Esc Enferm da USP 48(4): 663-669.

38. Hochgraf PB, Brasiliano S. Mulheres e substâncias psicoativas. In: Seibel SD, organizador. Dependência de drogas. 2ª edição São Paulo: Atheneu pp.1025-1042.

39. Mororó MEML, Colvero LA, Machado AL (2011) Os desafios da integralidade em um centro de atenção psicossocial e a produção de projetos terapêuticos. Revista da Escola de Enfermagem da USP 45(5): 1171-1176,

40. Vidal FDL,AraújoVS, Azevedo EV, Gaudêncio EO, Dias MD, Filha MOF (2012) Prática de cuidar/cuidado aos portadores de transtornos mentais: concepção dos enfermeiros. Ciência \& Saúde, Porto Alegre 5(2): 99-106 